\title{
Medicine as a Social Political Science The Case of Spain c. $1920^{*}$
}

\author{
Esteban Rodríguez-Ocaña
}

\section{Introduction}

ocial Medicine" was a complex and evolving set of principles that pro-
duced a particular understanding of the aims of public health and medi-
cine that highlighted the need to protect the great masses of population. It endowed doctors with a mission and made them authoritative agents of the salvation of nations, for the sake of science - a weak protection from racial and political prejudices. The label lacked a constant or universal meaning, depending on national and chronological contexts; consistently though, it dealt with some form of methodological relationship between social sciences and medical sciences. Great differences are found between developments in Germany and Central Europe regarding Great Britain, for instance, in the first half of the twentieth century, and similarly between Latin and North America in more recent times. ${ }^{1}$ In many places in Europe and Latin America, as in Spain, in the early 1950s it became the official name of a more or less thoroughly redefined academic discipline of Public

A preliminary version of this paper was presented at the EAHMH-SSHM Paris Conference, September 2005.

1 George Rosen, "What is Social Medicine? A Genetic Analysis of the Concept", Bull. Hist. Med., 21(1947), 674-733; Rudolf Thissen, Die Entwicklung der Terminologie auf dem Gebiet der Sozialhygiene und Sozialmezidin im deustchen Sprachgebiet bis etwa zunm Jahre 1930, (Düsseldorf, 1968); Erna Lesky, ed., Sozialmedizin, Entwicklung und Selbstverständnis (Darmstadt, 1977); Dorothy Watkins, "What was Social Medicine? A Historiography of the Concept (or, George Rosen Revisited)”, Bull. Soc. Hist. Med., no. 38 (1986), 47-51; Esteban Rodríguez-Ocaña, ed., "Introducción", in La constitución de la Medicina Social como disciplina en España, 1884-1923 (Madrid, 1987), pp. 9-51; Dorothy and Roy Porter, "What was Social Medicine?" J. Hist. Sociol. 1(1989), 90-106; Dorothy Porter, "Introduction", in Social medicine and medical sociology in the twentieth century (Amsterdam, 1997); Howard Waitzkin, Celia Iriart, Alfredo Estrada and Silvia Lamadrid, "Social medicine then and now: Lessons from Latin America. Amer J Pub Health, 91(2001), 1592-1601; Esteban Rodríguez-Ocaña, "La medicina como instrumento social", Trabajo Social y Salud, no. 43 (2002), 19-36. 
Health/Preventive Medicine. Playing names is an old tradition within public health, deeply rooted in its disciplinary structure such as has been critically depicted. $^{2}$

Present scholarship assumes that the gestation of social medicine started at the epoch of Enlightment and crystallised during the industrialization process, particularly around "the revolutions of 1848", as a new understanding of the human environment under the conditions of industrial life. Its basis stood on the growing strength of social sciences to describe and explain collective phenomena, particularly thanks to quantitative methods, as well as on the transformations of the complex health/disease/care linked to the development of laboratory sciences and the health transition. In the mid-nineteenth century, the term Hygiène sociale / soziale Hygiene was used to underscore the risks derived from urban living. At the beginnings of the twentieth century, as social insurances appeared and a number of mostly philanthropic interventions, known as health campaigns, developed, a series of teaching positions appeared, either for social medicine or for social hygiene, in Vienna (Ludwig Teleky, 1907), Düsseldorf (Schrakamp, 1909), Munich (Ignaz Kaup, 1912), or Berlin (Alfred Grotjahn, 1912 - who was later promoted to Ordinarius in 1921, the author of a paradigmatic lecture on Was ist und wozu treiben wir Soziale Hygiene? published in 1904). ${ }^{3}$ In countries such as Belgium or Italy medical associations of the same quality $(1913,1917)$ appeared also following the trail

2 Didier Fassin, "Comment faire de la santé publique avec des mots. Une rhétorique à l'œuvre”, Ruptures, revue transdiciplinaire en santé, 7 (2000), 58-78.

3 There is a long German tradition on the study of this topic; see, among others: Dietrich Tutzke, Alfred Grotjahn (Leipzig, 1979); Esteban Rodríguez-Ocaña, "Aproximación al concepto y práctica de la Medicina Social en Ludwig Teleky (1872-1957)”, Dynamis, 2 (1982), 299-323, and "La Academia de Higiene Social de Düsseldorf y el proceso de constitución de la Medicina Social como especialidad en Alemania", Dynamis, 3 (1983), 231-264; Daniel Nadav, Julius Moses und die Politik der Sozialhygiene in Deutschland (Gerlingen, 1985); Ulrich Koppitz and Alfons Labisch, eds., Adolf Gottstein. Erlebnisse und Erkenntnisse. Autobiographische und biographische Materialien (Berlin, 1999); Dietrich Milles and Norbert Schmacke, eds., Ludwig Teleky und die Westdeustche Sozialhygienische Akademie. Arbeiten für eine soziale Medizin (19031939) (Düsseldorf, 1999); Heinrich Weder, Sozialhygiene und pragmatische Gesundheitspolitik in der Weimarer Republik am Beispiel des Sozial- und Gewerbehygienikers Benno Chajes (18801938)(Husum, 2000); Gabrielle Moser, Sozialhygiene und öffentliches Gesundheitswesen in der Weimarer Republik und der frühen SBZ/DDR (Frankfurt a. M., 2002). Interest has now spread to broader circles, as with Dorothy Porter, ed., Social medicine and medical sociology in the twentieth century, (Amsterdam [Clio Med. 43], 1997); contributions by Paul Weindling, Gabriele Moser and Jochen Fleischhacker, Marcos Cueto, Lion Murard and Patrick Zylberman, and James A. Gillespie in Rodríguez-Ocaña, E., ed., The Politics of the Healthy Life, an International Perspective, (Sheffield, 2002); Patrick Zylberman, "Fewer Parallels than Antitheses: René Sand and Andrija Stampar on Social Medicine, 1919-1955", Soc. Hist. Med. 17 (2004), 77-92; Paul Weindling, "From Germ Theory to Social Medicine. Public Health 1880-1930", in: Deborah Brunton (ed), Medicine Transformed. Health, Disease and Society in Europe, 1800-1930, (Manchester, 2004), pp. 257-283. 
opened by the German Gesellschaft für soziale Medizin, Hygiene und Medizinalstatistik (1905). The European distinction between a 'social medicine' and a 'social hygiene' in the first decades of the twentieth century was mainly derived from the birth of a new field of medical practice related to social insurances, designed as "social medicine", while hygiene was used to denote the preventive domain. But the flourishing health campaigns drove care and prevention to merge, so that by the 1930s a broad consensus on the single title of social medicine was reached. The campaigns, directed towards great masses of population supposedly at risk for some condition among the so called "social diseases" (like VD, tuberculosis, infant or child mortality), blurred the distinction between health and illness, as they moved around the existence of environmental conditions that created danger for all people involved. At the same time, the new dispensaries or health centers did not wait for patients to come in, they went to search them instead, by direct inspection of homes, schools and the like. ${ }^{4}$

In this paper I analyse the Spanish contribution to this European trend. I particularly focus on the inter-professional groups that championed the banner of social medicine in Spain, as a rhetorical and social and political banner. But a thorough explanation requires a certain acquaintance with the Spanish medical literary tradition on the links between social sciences and medicine which I try to provide in the first place, looking at the forming of the key concept of social disease.

\section{The Place of the "Social" in the Medical World: The Making of Social Diseases}

From the extensive and systematic reading of Spanish texts produced in the first twenty years of last century, five notions can be singularized as the bricks of the social-medical discourse: i.e. the quantification of demographic phenomena, the economic value of health, the social etiology of disease, the danger of race degeneration and the reformist will. All of them are carried forward from the last half of the nineteenth century, the novelty being their addition in articulated forms, where most of them are present, during the first third of the twentieth century, therefore revealing the maturity of the discourse. ${ }^{5}$ All these concepts are connected by the

4 Esteban Rodríguez-Ocaña and Jorge Molero, "La cruzada por la salud. Las campañas sanitarias del primer tercio del siglo veinte en la construcción de la cultura de la salud", in L. Montiel, coord., La Salud en el Estado de Bienestar. Análisis histórico (Madrid, 1993), pp. 133-148. Jorge Molero and Francisco Martínez, "Las campañas sanitarias como paradigma de la acción social de la medicina", Trabajo Social y Salud, no. 43 (2002), 119-148.

5 Rodríguez-Ocaña (1987), "Introduction", see note 1. 
notion of quantity, which set itself as one of the central intellectual tenets of social life in the industrial world. ${ }^{6}$

The analogy between the human body and the social body is known since the time of ancient Greek thinkers, like Aristotle, and was a working metaphor during the second half of the nineteenth century due to the influence of Herbert Spencer's doctrine. The combined ideas of evolutionism, originally Lamarckian, and scientific positivism, affected by a Darwinian bias as we get closer to the end of the century, were crucial for the forming of Sociology. As it has recently been shown for the case of France, by the last two decades of the nineteenth century practically all social discourse employed a biological or medical rhetoric, which in itself became a metanarrative. ${ }^{7}$ Medicine, on its side, grew in scientific consistency thanks to development of basic biological sciences, such as physiology, microbiology and others, while the broadening of healthcare facilities produced a decently bourgeois way of living for generations of practitioners. In fact, it boasted of being one of the paradigmatic professions of the industrial, liberal society. This notwithstanding, socially eminent practitioners sought also to produce a stronger link with the dominant elite, which they achieved by sharing the same rhetorical facilities. That is, during decades they applied the correspondence biology/society, to describe and to explain social processes in biological terms and from the beginnings of the twentieth century they applied social terms to explain medical matters.

The forming of the concept of social disease can help us to produce some examples.

The first condition so defined was pauperism, "a congenital social disease". Indeed, mid nineteenth century authors looked at society through a medical gaze that defined "diseases" instead of social disorders. The author responsible for this quotation, Pedro F. Monlau (1808-1871), a reputed hygienist, became a fellow of the Academy of Moral and Political Sciences in 1870, where he read a paper on Social Pathology. A brief study on crime. ${ }^{9}$ Again, the same metaphor: any challenging

6 Theodore M. Porter, Trust in Numbers. The pursuit of objectivity in science and public life (Princeton, 1995); Iris Borowy, "Counting death and disease: classification of death and disease in the interwar years, 1919-1939", Continuity and Change, 18 (2003), 457-481.

7 Snait Gissis, "Late Nineteenth Century Lamarckism and French Sociology", Perspectives on Science, 10 (2002), 69-122.

8 Pedro Felipe Monlau, "Remedios del pauperismo", El Amigo del País (Madrid), 1846, pp. 213-215 [reprinted in Estudios de Historia Social, no. 10-11 (1979), pp. 374-385].

9 Mercedes Granjel, Pedro Felipe Monlau y la Higiene española del siglo XIX (Salamanca, 1983); Rafael Alcaide González, "La introducción y el desarrollo del higienismo en España durante el siglo XIX. Precursores, continuadores y marco legal de un proyecto científico y social", Scripta Nova. Revista Electrónica de Geografia y Ciencias Sociales, no. 50 (1999), [http://www.ub.es/ geocrit/sn.50-htm]. Ricardo Campos, Monlau, Rubio, Giné. Curar y gobernar. Medicina y liberalismo en la España del siglo XIX, (Tres Cantos, Madrid, 2003). Esteban Rodríguez-Ocaña, "Confort, ornementation, hygiène. Modernisation urbaine et hygiénisme dans 
of the order of society (as decided by the ruling class) should be depicted as a disease. In this paper, an argument is made in favour of the death penalty as the elective treatment in case of riots or rebellions. Those were the days of the short lived First Spanish Republic (1870-1872).

Later, in a context of political stability, another Hygiene professor of Madrid University sustained that social diseases were "those that are able to influence the physical and moral sides of individuals as well as to distort the social organism"; he then listed prostitution, alcoholism, vagrancy and beggary, gambling, murdering and suicide. ${ }^{10}$ Accordingly, the prominent surgeon Federico Rubio (1827-1902) included under the same proposition all "public disasters" by any cause — ranking from telluric to zymotic to distortion of social classes-, the "individual vices" (such as alcoholism, nicotism, prostitution and the like) for they impinged upon families and communities, and the "collective vices", which included non-democratic political organisation, ignorance, pauperism and functional disorders as strikes or riots. ${ }^{11}$

Both Angel Larra (1858-1910, a high Navy medical officer) in Madrid, in 1902, and Ignaci Valentí Vivó (1841-1924, Professor of Forensic Medicine), in Barcelona, in 1905, stuck to the opinion that explained social pathology as a parallel phenomenon to medical pathology; but where Larra considered the sociological trail as a guide to the study of medicine, particularly hygiene, Valentí highlighted the influence of medical rationale on the forming of sociological concepts in the realm of Economics. ${ }^{12}$ Significantly in both cases they referred to Paul (Pavel) Lilienfeld as source of authority, a partner of René Worms at the International Institute of Sociology, a well known fellow of the social-organismic tendency of fin-de-siècle sociology.

l'Espagne du XIXe siècle", in Patrice Bourdelais, dir., Les Hygiénistes: enjeux, modèles et pratiques (Paris, 2001), pp. 297-318.

10 Francisco Javier Santero, Elementos de Higiene Privada y Pública (Madrid, 1885), II, p. 487.

11 Federico Rubio, "(La Socio-Patología.) Discursos leídos en la solemne sesión inaugural del año 1890 de la Real Academia de Medicina”, Memorias de la Real Academia de Medicina de Madrid 10, no. 5 (1890), 25-49. See Campos, Monlau, ( 2003) note 8 and Juan L. Carrillo Martos, ed., Medicina y sociedad en la España de la segunda mitad del siglo XIX: una aproximación a la obra de Federico Rubio y Gali (1827-1902) (El Puerto de Santa María, 2003).

12 Ángel de Larra y Cerezo, "Los grandes problemas higiénicos y sociales en relación con las instituciones armadas", Discursos leidos en la Real Academia de Medicina... el día 9 de noviembre de 1902 (Madrid, 1902), p. 35; Ignacio Valentí Vivó, La sanidad social y los obreros. Ensayo antropológico (Barcelona, 1905), II, p. 112.

13 Paul Lilienfeld, La Pathologie sociale (Paris, 1896). See Gissis (2002), note 6, and Ulrike Schuerkens, "Les Congrès de l'Institut International de Sociologie de 1894 à 1930 et l'internationalisation de la sociologie", International Review of Sociology, 6(1996), 7-24, also at http://www.tau.ac.il/-iisoc/history.html. 
No doubt, in the words of prominent professors and most respected citizens, "among all traditional professions, Medicine is the genuinely biological and social", and particularly as Public Health, "is intended to solve the most difficult problems of life in great groups".

Through this display of selected quotations, I have tried to show the factual coexistence of both fields of experience, from the natural and from the social sciences of their time, in the minds and voices of medical writers by the end of the nineteenth century, who seemed happy to explain the social world through medical patterns. But as far as the medical gaze focused on human groupings - which, simultaneously, meant a concern over the problems of governance - the social sciences gained in utility to the medical world.

Let's look to the definition employed by Philip Hauser (1832-1925) - a Jewish physician migrated to Spain from the AustroHungarian Empire, and prolific writer. ${ }^{15}$ In a fine monograph of 1884 , Hauser analysed its time "from a social medical point of view", showing the increase of nervous disorders and mental diseases, alcoholism, tobaccoism, syphilis, nutritional dystrophy, pulmonary consumption, abdominal typhus and diphtheria. These should be all considered as social diseases, for, first, they sprang "inherent to the vicious organization of society". ${ }^{16}$ Secondly, they had to be considered social diseases because of their "ubiquity", i.e. their huge number of victims and last but not least, their consequences on race as "weakening agents" should also be considered. The two last conditions were intimately close to the economic reasoning that summarizes deaths and illnesses in monetary terms and that Chadwick, Pettenkofer or Rochard had turned into fashionable accounting.

Therefore, the "social" condition impinged over the cause, the number of affected and the collective consequences of any given disease. Positivistic minds favoured taking the road of quantification, which in Spain was facilitated by the opening of the National Civil Register in 1871 (although the publication of the series on the Annual Movement of Population started only in 1902). ${ }^{17}$ As Barcelona province and municipality were the leading administrations in implementing such demographic tools, quantitative studies on health became a regular feature of the

14 Ignacio Valentí, Discursos leidos en la Academia de Higiene de Cataluña (Barcelona, 1892), p. 54; Francisco Laborde y Winthuyssen, Lecciones de Higiene Privada y Pública (Sevilla, 1894), II, p. 8.

15 Juan Luis Carrillo, ed., Entre Sevilla y Madrid. Estudios sobre Hauser y su entorno (Sevilla, 1996) and Entre Sevilla y Madrid. Nuevos estudios sobre Hauser y su obra (Sevilla, 1999).

16 P. Hauser, "El siglo XIX considerado bajo el punto de vista médico-social", Revista de España, 101(1884), 202-224; 333-358 (p. 219).

17 E. Rodríguez-Ocaña and Josep Bernabeu-Mestre, "Physicians and statisticians. Two ways of creating the Health Statistics in Spain", Continuity and Change, 12(1997), 247-264. 
Urban Hygiene Institute of the city of Barcelona from the 1870 s on. ${ }^{18}$ Luis Comenge (1854-1916), at the time director of the Institute, plot demographic against other economic and social data in 1899 looking for a fuller description of the urban mortality figures up to 13 years of age. A classification was drawn taking into account income levels, cost of renting, type of funeral and place of death, which resulted in a three-layered picture of Barcelonian society, composed by poor, moderate and rich families. Using the death rates found among the rich as a level of comparison, Comenge described an increasing proportion of young deaths as the families departed from that level. ${ }^{19}$

Thus, the pursuit of quantitative studies on population became the way of election to the display of diseases and its harmful consequences as social objects, therefore contributing to the establishment of the idea of a social etiology. Social diseases so constructed in turn acted as irritant spines on the consciousness of intelligentsia and pushed it to act. In the liberal world, private philanthropy played a decisive role on the launching of public interventions that were called health campaigns.

Thus, at least since the 1860s there existed a wide acceptance of the idea of the paramount importance of poor housing and nutrition, as well as moral corruption, on the causation of tuberculosis. Although such opinion was mainly based on the professional experience of doctors, quantitative studies started to be led from 1895 on, linking specific deaths with social conditions, as in Madrid and Barcelona. This quantitative evidence fuelled the organisation of several initiatives from the civil society intended to curb this evil, from 1899 to 1907, that evolved into a single national organisation in 1924 . Urban dispensaries and mountain sanatoria were the places of the fight against tuberculosis, health education its principal weapon. Statistical accounts of the task of dispensaries, started in 1912, brought new evidence on inequalities. ${ }^{20}$

Another important trend of local demographic studies was centered on infant and child mortality. ${ }^{21}$ At first, the numerical evidence served to produce grief and sorrow, a picture of a national catastrophe, and to point out strong social inequalities, but by

18 E. Rodríguez-Ocaña, "La labor estadística de Luis Comenge (1854-1916) en el Instituto de Higiene Urbana de Barcelona”, Dynamis 5-6 (1986), 279-306.

19 There were 34,33 rich people dead among every 100 of its class, and the number increased to 38,94 among the moderate class and to 44,49 among the poor class.

20 Jorge Molero, "Tuberculosis como enfermedad social en España", in: J. Molero, ed., Estudios médicosociales sobre la tuberculosis en la España de la Restauración (Madrid, 1987), pp.1421; and "La tuberculosis como enfermedad social en los estudios epidemiológicos españoles anterior a la guerra civil”, Dynamis, 9 (1989), pp. 185-223.

21 For further precisions on this subject, see Aron Cohen, "La infancia entre la vida y la muerte: la mortalidad de los niños", in J.M. Borrás Llop, dir., Historia de la infancia en la España contemporánea, 1834-1936 (Madrid, 1996), pp. 109-148; 185-188; E. Rodríguez-Ocaña, "La construcción de la salud infantil. Ciencia, medicina y educación en la transición sanitaria en España”, Historia contemporánea, no. 18 (1999), 19-52. 
1900 it turned into an argument to foster health interventions that led to the developing of a new field of medical practice, under the mid-nineteenth century French name of Puericultura (Puériculture). It was defined as "the medical and social activity needed to protect natality, to curb mortality and therefore aimed to sustaining the rise of the population". ${ }^{22}$ It had to do with the technical guidance of child rearing and leaned over the shoulders of women, either mothers or mothers-to be. Physicians, then, saw themselves as a kind of preceptors, who sought to free women from the bonds of superstition and traditional habits and to educate then in the new scientific culture ("scientific motherhood" as Apple put it).

The weight of social considerations made that, in such process, individual rights became subordinated to higher strategic purposes, meaning that forceful measures could be applied in order to modify risky behaviour as long as it carried any danger to the public health. A Nation's body stood over infants' bodies, who "although they are linked by blood to their families, they belong to the Fatherland". ${ }^{24}$ Such was the spirit of the legislation passed for the protection of infancy and childhood in 1904 as well as the sustaining argument in the development of private and municipal caring centers such as Milk Stations and Well-babies' clinics, that spread over cities.

The definition of an ailment as a "social disease" became an outstanding rhetorical device to attract public interest, and consequently money and jobs which produce new specialties through the timely health campaigns. That which was happening around infant mortality or tuberculosis, served as a model for what was sought concerning other conditions. The main contribution to the knowledge of a new public health problem - first observed at the end of the previous century - was significantly titled Ankylostomiasis or miners' anaemia as a social disease (1912). It emphasized its danger as a disaster to industry and a catastrophe to some territories, even though its epidemiological basis was weak, just composed of the working and clinical records of some sixty miners and of an enquiry among some mine doctors. Not surprisingly, its effects were compared to those of tuberculosis. ${ }^{25}$

22 Jesús Sarabia y Pardo, Discurso leido en la sesión inaugural del año académico de 1913 en la Sociedad Ginecológica Española por el presidente de la misma (Madrid, 1913), p. 6.

23 Rima Apple, "Constructing Mothers: Scientific Motherhood in the Nineteenth and Twentieth Centuries”, Soc. Hist. Med., 8 (1995), 161-178.

24 Juan Aguirre y Barrio, Mortalidad en la primera infancia, sus causas y medios de atenuarlas (Madrid, 1885), p. 250.

25 José Codina Castellví, La anquilostomiasis ó anemia de los mineros como enfermedad social, especialmente en España, (Madrid, 1912), p. 25. On this subject, see E. Rodríguez-Ocaña and Alfredo Menéndez, "Higiene contra la anemia de los minerso. La lucha contra la anquilostomiasis en España (1897-1936)", Asclepio, 58/1 (2006), 219-248. On the relationship of health campaigns and the forging of new specialties, Rosa M. Medina and E. Rodríguez-Ocaña, "Profesionalización médica y campañas sanitarias en la España del siglo XX", Dynamis, 14 (1994), 77-94. 
These studies on local data matched a long standing strand of international literature, producing the corollary that disease and poverty, poverty and disease, joined in a chain that held the greater part of society in a subordinate position. This particular metaphor of a vicious circle chaining workers to poverty was employed by Francisco Murillo (1865-1944) - a member of the National Institute of Hygiene who was later to become head of the General Directorate for Public Health - as one of his main arguments in favour of the implementing of social insurances in $1918 .^{26}$ The same metaphor can be also found in the arguments employed by René Sand (1877-1953) as he turned "from a sociological biology to a social epidemiology" in the early 1930 s. $^{27}$

However, the development of microbiology posited new explanations that challenged at first the older social paradigm. Hauser (1902) recognized this challenge and drew a distinction between infectious and "true" social diseases (comprising alcoholism, syphilis and consumption) (at that moment, Hauser was 70 years old). ${ }^{28}$ He thus primed the global degenerative effects of diseases as the core tenet for its social definition but, in general, the question was solved thanks to the numerical method, and the social label was applied to all disorders (including transmissible diseases) that affected the populations at a great scale, in account of their economic and racial outcomes and consequences on the strength of the nation. An extensively distributed handbook circa 1910 by Alfredo Opisso (1847-1924) - a very prolific medical translator and publicist, who contributed heavily to some successful paperback series (Manuales Soler, and Manuales Gallart) intended to the dissemination of knowledge - included a section on "social diseases", listing anaemia, slow starvation, tuberculosis, alcoholism, venereal disease, madness, neurasthenia, heart diseases, arteriosclerosis and brain stroke, several epidemic and endemic diseases, cancer, unhealthy industrial shops, women's work, diseases at school, animal diseases transmissible to human beings, infant mortality, depopulation and crime. As we may see, the list is not made upon a single axis, and together with purely anatomi$\mathrm{cal}$ and pathophysiological disorders there can be found conditions linked to modern patterns of life as well as conditions that are read as diseases of the political body, such as the last two. ${ }^{29}$

Remainders of the old view of social pathology, corresponding to a medical reading of the evils of society, some physicians defended a direct modelling of the

26 Francisco Murillo Palacios, "La defensa social de la salud pública", Discursos leídos en la Real Academia de Medicina... el día 14 de julio de 1918 (Madrid, 1918), pp. 11-60.

27 Patrick Zylberman, "Hereditary disease and environmental factors in the "mixed economy' of public health. René Sand and French social medicine (1920-1934)”, in J. P. Gaudillière and I. Löwy, eds., Heredity and infection. The history of disease transmission (London, 2001), p. 267.

28 Ph. Hauser, Madrid bajo el punto de vista médico social (Madrid, 1902), I, pp. 49-50.

29 Alfredo Opisso Viñas, Medicina social. Estudio de las enfermedades colectivas, sus causas, profilaxis y remedios, Manuales Soler, no. 78 (Barcelona, c. 1910). 
human society on biological organisms and discussed "the wrong functioning of cells that form the Nation" ${ }^{30}$ by "applying the laws of medical pathology". ${ }^{31}$

Manuel López Comas, Provincial Officer of Health of the Balearic Islands, in 1907 defended the change of name of the former Public Hygiene into a new Social Hygiene, that comprised both a theoretical part, based on sociology, and an applied part (Sanidad), which resulted in the application of those theoretical principles to the guidance of people (in the sense of governance). López Comas also pointed out that public health as thus defined should keep "an indissoluble partnership" with the public charities organisation (Beneficencia pública). ${ }^{32}$

The link between social hygiene and the public schemes of healthcare, that is between the description of population effects of widely suffered diseases, the study of their causes, the invention of means of protection against them and the provision of actual care for those in need, gave way to the label of social medicine being applied to this special set of medical theory and practice, which eventually won over the former. Early evidence can be found in Opisso's work (c. 1910) already quoted, where the definition of social medicine joined aspects of pathology, hygiene, sociology and political economy - albeit recognising that as a discipline it stood still "on an embryonic state". This view stressed the value of applying knowledge, through some "hygienic institutions", as the sole way to fight collective diseases; therefore, the character of this medicine departed from that of clinical medicine, centered on the individual.

\section{A Political Character for Social Medicine}

The politics of formally democratic Spanish Monarchy, since its Restoration in 1875, were based on a broad agreement between two parties, Conservative and Liberal, of a marked oligarchic character, which substituted each other as the government at the Monarch's will. In this context, general elections played a subsidiary role, being the expression of the change in the central offices. The system cracked after the 1898 war, stagnated between 1909 (riots of the so called Tragic Week) and 1913 (murder of the Liberal Prime Minister José Canalejas) due to the fragmentation of the parties, and finally collapsed, as it was unable to integrate the emerging new actors in the social scene, such as Labour representatives, Regionalists and Republicans. From 1917 on, the political situation deteriorated rapidly due to growing social unrest, with an unparalleled number and duration of strikes, as

30 Saturnino García Hurtado, Ensayo de Patología Social (Madrid, 1909), p. 12.

31 Pedro Martínez Baselga, Las penas del hombre: Patologia social española (Zaragoza, 1903), p. 4.

32 Manuel López Comas, "Sentido sociológico de la sanidad pública”, Rev. balear de ciencias médicas, 29 (1907), 141-153; 161-173. 
much in industrial as in rural areas, spreading enormous fear among the well-off classes. ${ }^{33}$

Anyhow, a deep change in the moods of government came after 1898; laissez faire politics and forceful repression transformed into an interventionist stance on social relationships. Accordingly, a flood of medical (or health-seeking) projects, proposed by physicians but formally open to diverse contributors, spurred including attempts to modernise the health administration. We can observe the lead of Catalonian initiatives over centralist ones at Madrid, a common feature of this time in the modern history of Spain, and that practically all were couched within the social medicine stance. Now I propose to follow the most significant of them.

The Catalonian Academy of Hygiene (CAH), gathered practically all Catalonian doctors who cared about large-scale implementation of modern hygiene. It was born in 1887, as a by-product of the process of generation of a Spanish Society for Hygiene, first launched in Barcelona around the publishers and contributors to the medical journal named Gaceta médica catalana but finally achieved in Madrid (1883) by the medical group around El Siglo Médico, the established leader of Spanish medical journalism. ${ }^{34}$ Consequently, CAH became instrumental in the coming to being of the Patronato de Cataluña para la lucha antituberculosa (1903), a Board to fund and manage the first Dispensaries against tuberculosis, that after 1909 were merged with the general Spanish organisation.

In 1906, the CAH organised a first open conference, one of its three sections being dedicated to social hygiene. The contents of this session included three invited papers that dealt with core problems of industrial life (housing for workers, dust producing industrial processes and work accidents), and six registered papers, three on infant and child hygiene and two on venereal diseases. As wrote one of the most enthusiastic among its members, Jaume Queraltó i Ros (1868-1932), "hygiene, at the summit of its development, becomes the social science par excellence". ${ }^{35}$

Conducted by the same Queraltó, between April 1911 and November 1912 a Catalonian Institute for Social Medicine, Institut Médic-Social de Catalunya, organised several public series of lectures, up to some seventy, at the Ateneo of Barcelona, a private cultural circle of the Regionalist intelligentisa, and at the Ateneo obrero, a similar institution created by workers, to publicize "the betterment of medicine and social relations". His main character, Queraltó, was at the time the personal physician of Anselmo Lorenzo, one of the great names of Anarchist unionism. Among

33 F. del Rey Reguillo, "El empresario, el sindicalista y el miedo" in: R. Cruz and M. Pérez Ledesma, eds., Cultura y movilización en la España contemporánea (Madrid, 1997), pp. 235272.

34 Rodríguez Ocaña (2001), “Confort,...”, note 9.

35 Queraltó, La tasca social de I'Higiene (Barcelona, 1907), p. 15. 
the forty lecturers one finds university professors, well-known physicians and lawyers, even the chief prosecutor of the province of Barcelona, together with a couple of known Anarchists and several Republican doctors. Nevertheless, the Institute enjoyed some official funding from the highest civil and military authorities until the forced exile of his mentor to Madrid, where he lived until 1917, put an end to these endeavours.

Another official of the CAH, its President in 1909 and President of the Tuberculosis Board in 1911, Enric O. Raduá i Oriol, a municipal medical officer since 1896, contributed with the funding of a journal, Medicina Social, that lasted between 1911 and 1919. Its clear subtitle read: Monthly review of hygiene, demography, social medicine, pedagogy and sociology. It followed a short lived adventure, the Revista Demográfica y Social (social and demographic journal) of 1908. The editorial board included more than a dozen physicians, mostly extracted from the circles of medical Catalanism, as well as one engineer, one architect and one lawyer. At the head of the 65 contributors, the chief editor produced a rough $25 \%$ of all articles. The key questions were mortality statistics - for years, Raduá held a position in the municipal office for health statistics - and the fight against tuberculosis.

These Catalonian initiatives found a tardy echo in the capital of the Kingdom, where also a journal and an institute devoted to social medicine were created during the critical conjuncture of 1917-1920.

As stated before, the political system was totally upset by 1917. Internal reasons add to external sources of concern, as were the colonial war in Northern Morocco, derived from an agreement with France and England of 1912, and none the less, the Great European War. Spain kept neutral, although Conservative leaders and most of the high command of the Army, including King Alphonse were in favour of Central Empires - which in turn helped the Allied cause to grow close to Republicanism and the Left. Not surprisingly, the opposing aims by Western and Central powers concerning Spain ended up favouring both the same outcome, a severe social and economic instability. ${ }^{36}$ The flu epidemics of 1918-1919 increased drama with the deep disruption of social life it brought about, not less than by the dismal feelings of impotence associated and by its heavy toll of victims. ${ }^{37}$

In front of such crises, professional groups, a part of the growing urban bourgeosie, developed an original answer of their own mainly composed by proposals on

36 Carlos Seco Serrano. Alfonso XIII y la crisis de la Restauración (3rd. ed., Madrid, 1992); Francisco J. Romero Salvadó, España 1914-1918. Entre la guerra y la revolución (Barcelona, 1999).

37 E. Rodríguez-Ocaña, "La Grip a Barcelona. Un greu problema esporàdic de salut pública. Epidèmies de 1889-1890 i 1918-1919», in: Cent anys de Salut Pública a Barcelona (Barcelona, 1991), pp. 131-156; Isabel Porras Gallo, Un reto para la sociedad madrileña: la epidemia de gripe de 1918-1919 (Madrid, 1997); Beatriz Echeverri, La gripe española. La pandemia de 19181919 en España (Madrid, 1993). 
the health domain. ${ }^{38}$ In 1917 and 1918, the first official discussion on national health insurances was led. Ideas were drawn on "nationalization of medicine", that crawled into painstaking and unsuccessful parliamentary negotiations over a new Health Law to substitute the obsolete version of 1855. Medical journals launched a campaign asking for an independent Health Ministry, which they all described as an independent technical institution, conducted by a prestigious medical doctor and protected against the frequent changes in office that were the norm for the government in those days. Following the ravages of the flu epidemic, words were heard in favor of una dictadura sanitaria (a public health dictatorship).

The professional mind favoured an understanding of political crisis in terms of technical inefficiency. This tendency supported the opinion, then expressed by younger intellectuals as José Ortega y Gasset (1883-1955), about the legitimacy of professional elites to conduct the masses of the people, due to their knowledge and expertise. ${ }^{39}$ This political direction included a strong commitment with education, and one of the public enterprises of this period led by philosopher Ortega was the foundation of a League for Political Education (1913).

Such was the moment of the greatest visibility for social medical discourse, aimed to curb social conflicts and to produce a peaceful relation among classes. As previously said, a journal (La Medicina Social Española, 1917-1920) and an Institute of Social Medicine (1919-1923) were created in Madrid, but encompassing the whole nation. The journal and the Institute seemingly addressed different circles; while the former mobilized the newly formed corps of health officers, and kept links with the Conservative fraction led by Juan de la Cierva Peñafiel (1862-1938) an epitome of law and order, the later recruited members among the professional elite and had an array of political sensibilities represented, including some prominent Conservative lawyer and social scientist Manuel Burgos Mazo (1862-1946), Republican and philo-Anarchist publicists as Odón de Buen (1863-1945) or José García Viñas (1838-1931).

The editor in chief of the journal was the general secretary of the official Commission against tuberculosis, Bernabé Malo de Poveda (1844-1926) - who later counted as correspondent among the members of the Institute. Its first issue dressed a roll of 132 contributors, 45 among them were provincial health officers (practi-

38 Hedwig Herold-Schmidt, Gesundheit und Parlamentarismus in Spanien. Die Politik der Cortes und die öffentliche Gesundheitsfürsorge in der Restaurationszeit (1876-1923) (Husum, 1999); Rafael Huertas, "Fuerzas sociales y desarrollo de la Salud Pública en España, 1917-1923", Rev. San. Hig. Pub., 68 (monograph issue II Encuentro Marcelino Pascua) (1994), 45-55; Rafael Huertas, "Medicina y política en la crisis final de la Restauración. La propuesta de un Ministerio de Sanidad", in M. Nash and R. Ballester, eds., Mulheres, trabalho e reproduçao. Attitudes sociais e politicas de protecçao à vida (Porto, 1996), pp. 285-299; M. Isabel Porras Gallo, "La lucha contra las enfermedades evitables en España y la pandemia de gripe", Dynamis 14 (1994), 159-183.

39 Francisco Villacorta, Burguesía y cultura: Los intelectuales españoles y la sociedad liberal, 1808-1931 (Madrid, 1980). 
cally, all there existed at that time), 21 were university professors and a great deal of the rest, physicians employed by the administration. In 1920, the list was reduced to 47 contributors. The founding of the journal responded to "social needs scarcely met", which had given rise to a "clear, well defined movement" (Med. Soc. Esp. 1916; 1: 7-8), that sought to promote a Spanish Company of Social Medical Institutions, which never went true due to the failure of the journal (Med. Soc. Esp. $1920 ; 5: 1-3)$. It was written that the operation was known and approved by de la Cierva and the King. Its content was fairly exhaustive; the greatest number of papers appeared under the general heading of Hygiene and public health (28\%), followed by those on Tuberculosis (18\%), Infectious diseases (17\%) and Infant and child diseases (9\%). A section of Feminist Notes (12\%) displayed for the first time in a systematic way comments and analysis on matters related to women and health, most of the papers written by medical women or by women teachers. Of the nine authors that contributed with more than the half of all published papers, three were also women: Concepción Aleixandre (one of the first women to win a medical license, in 1886) and the teachers Concepción Saiz de Otero and María Carbonell.

The Institute for Social Medicine, which has become a token to research on the introduction of Eugenics in Spain, aimed to renew or "regenerate" the health situation of the state, through the education of population and the guidance of authorities, as the only means to put an end to social conflict. ${ }^{40}$ Therefore, their membership was open to other than physicians, and lawyers, educators and military personnel joined it, in numbers that doubled, in less than one year, the initial list of 270 members. For instance, more than a dozen high Navy officers, including the chief of the health services, fourteen provincial health officers, three professors of forensic medicine and two of hygiene were included. The call to form the Institute was expounded in the last weeks of 1918 through an exchange of public letters between two physicians, a military one expert in psychiatry, César Juarros (18791942), and Antonio Aguado - related to Antonio Piga, professor of Forensic medicine at the University of Madrid, who was also among the earliest members. ${ }^{41}$ The 1st January 1919, a founding board of twenty fellows, fifteen physicians, two lawyers, one Navy officer, one veterinary surgeon and one educator settled its consti-

40 Raquel Álvarez Peláez, "El Instituto de Medicina Social: primeros intentos de institucionalizar la eugenesia (en España)", Asclepio, 40 (1988), 343-358; "Introducción al estudio de la Eugenesia española (1900-1936)", Quipu 2 (1985), 95-122; and, "El pensamiento evolucionista y su influencia en las ideas medico-sociales durante el primer tercio del siglo XX", in Miguel Angel Puig-Samper, R. Ruiz and Andrés Galera, eds., Evolucionismo y cultura. Darwinismo en Europa e Iberoamérica (Madrid, 2002).

41 Pedro Samblás, "El Dr. César Juarros y la Escuela Central de Anormales”, in José Martínez-Pérez et al., eds., La Medicina ante el nuevo milenio: una perspectiva histórica (Cuenca, 2004), pp. 539-550 ; and "César Juarros y el Tratamiento de la morfinomanía: ¿cura u ortopedia? ", Frenia, 2 (2002), 123-137. Antonio Piga, A. Aguado Marinoni, Las bebidas alcohólicas. El alcoholismo, Manuales Soler, \#52 (Barcelona, c. 1910). 
tution. The Institute divided into four sections, respectively aimed to 1. "the study of Spain as a social body", 2. teaching, 3. publicity and 4. political action. In practice, its activity was reduced to lectures and pamphlets, such as $A$ popular primer on social medicine $e^{42}$ but it associated with others (the Red Cross, the Madrid provincial Medical Association and the Spanish section of the International Group Pro Humanité, unregistered in any known previous study) to build of a Spanish League for Social Medicine (1920-1923) that searched to conduct government decisions with "biological sense".

Some relevant members of the Institute took part in a Social Medical Week, held in honour of the Royal Family at their vacation resort in Santander, in August $1920 .{ }^{43}$ Alphonse XIII, at the inauguration of the lectures, described two paramount health problems, tuberculosis and malaria, as the axes around which health policies should developed. Subsequently, the Chief Health Officer, Manuel Martin Salazar (1854-1937), ${ }^{44}$ boasted that thanks to His Majesty's words, the government had given him a supplementary budget worth half a million pesetas to public health purposes. This was the formal excuse to the beginning of the organised fight against malaria, under the direction of Gustavo Pittaluga (1876-1956), ${ }^{45}$ although the budget was rejected by Parliament and the money was never made available. Pittaluga coined a definition of Spain's main health problem as the need to implement interventionist policies - sustained by the science of hygiene, the technical devices of public health and the will to act through social medicine. ${ }^{46}$ Malaria was an extensive, century-old handicapping condition for extensive rural regions in Spain that became a "social disease" once peasants grew to political subjects.

To conclude and summarize: the analogy biology/society cherished by first wave sociologists in the nineteenth century was sustained and used by Spanish medical writers. If during many years, this use could be considered mainly a pure figure of speech, a rhetorical style shared with other layers of the professional elites to discuss about contemporary problems of social life and politics, there was a moment -

42 A. Aguado Marinoni and Luis Huerta, Cartilla popular de Medicina Social (Madrid, 1919).

43 Manuel Martín Salazar, "La Semana Médico-social de Santander", Med. Soc. Esp. 5(1920), 385-392.

44 Francisco Salas Fernández, Manuel Martín Salazar. Apuntes biográficos (Sevilla, 1998), also available at http://fcosalas.eresmas.com/frames.html.

45 Esteban Rodríguez-Ocaña, "International Health Goals and Social Reform: The Fight against Malaria in Interwar Spain", in I. Borowy and W. D. Gruner, eds., Facing Illness in Troubled Times. Health in Europe in the Interwar Years, 1918-1939 (Frankfurt A.M., 2005), pp. 247276. E. Rodríguez Ocaña, Rosa Ballester, Enrique Perdiguero, Rosa M. Medina and Jorge Molero, La acción médico-social contra el paludismo en la España metropolitana y colonial del siglo XX (Madrid, 2003).

46 Gustavo Pittaluga, El problema político de la sanidad pública, (Madrid, 1921). 
around the new century - when social methods (quantitative) and social worries served as a way of constructing a medical thought. Doctors started to explain medical matters in social terms, as they strove in search of massive programmes of prevention and care. Political crisis and growing professional ideology, though, helped to instil a new life to the old analogy and physicians - not only public health people - sought to serve their country providing a (social) biological guidance to governments and a (social) biological education to the people. Social medicine in Spain, from the 1920s to the 1960s produced a deep influence on the shaping of public health policies, no matter the political regime.

Esteban Rodriguez-Ocaña is professor at the Department of History of Science, University of Granada, Granada-Spain. 